\section{SOI: 1.1/TAS DOI: 10.15863/TAS International Scientific Journal Theoretical \& Applied Science}

p-ISSN: 2308-4944 (print)

e-ISSN: 2409-0085 (online)

Year: 2018

Issue: 02

Volume: 58

Published: 20.02 .2018

http://T-Science.org

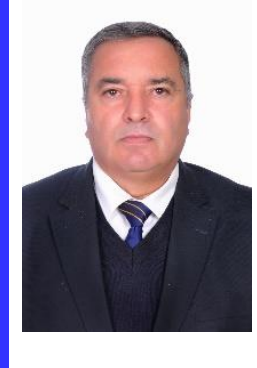

Hasan A. Mammadov Department of World Economy and Management, Nakhchivan State University, Nakhchivan Uneversity Campus, Nakhchivan, Azerbaijan Respublic hasan_1961@mail.ru

SECTION 31. Economic research, finance, innovation, risk management.

\title{
THE IMPROVEMENT OF INFRASTRUCTURES USING THE LEADING WORLD EXPERIENCE
}

Abstract: In the article, research is underway to improve the infrastructure of the country by ensuring the sustainable development of the Azerbaijani economy and the preparation of infrastructure projects and the use of advanced world experience. For this purpose, advanced practices of the USA, France, England, Turkey, Russia, Kazakhstan, Belarus, Sri Lanka and Malaysia are on the foreground. It is noted that, based on the best international practices, infrastructure, management, development and perfection of form, and other forms of public-private lease, joint venture and industrial areas (neighborhoods) could be useful in the application forms. At the end, studies are summarized and recommendations are made to eliminate existing problems and improve the development of infrastructures affecting the sustainable economic development of the Republic of Azerbaijan.

Key words: advanced world experience, public-private form, rental, joint venture, industrial areas, industrial neighborhoods.

Language: English

Citation: Mammadov HA (2018) THE IMPROVEMENT OF INFRASTRUCTURES USING THE LEADING WORLD EXPERIENCE. ISJ Theoretical \& Applied Science, 02 (58): 74-80.

Soi: $\mathrm{http} / / / \mathrm{s}-\mathrm{o}-\mathrm{i} .0 \mathrm{~g} g / 1.1 / \mathrm{TAS}-02-58-18$ Doi: crossef https://dx.doi.org/10.15863/TAS.2018.02.58.18

\section{Introduction}

As well as in every country in the world, purposeful measures for the perfect preparation of infrastructure projects and the organization of their solution are of particular importance in ensuring the sustainable development of the Azerbaijani economy. As a result, since 2004, the Government of Azerbaijan has adopted a series of state programs for the sustainable development of the economy. In each of these state programs, the creation, development and improvement of infrastructures, along with other areas, is on the foreground.

Research shows that the implementation of infrastructure projects over the past 13 years by local and foreign financial sources of investment has been involved in a considerable amount. As a result, since 2004, restoration and reconstruction of infrastructure has been begun in all regions, production and social facilities, infrastructure facilities serving them have been created, and this work is still being continued today (Perry, 2010).

Recent global economic changes, including a decline in the aggregate demand in the international market over the aggregate supply, the fall in world oil and oil prices, and the decline in international trade have led to stagnation in the global economy.
The severe consequences of the global economic crisis have not yet been overlooked by the Azerbaijani economy. However, in order to minimize the impact of the current situation on economic development and to maintain sustainable development stability, it was important to develop the domestic market through local resources and to ensure the implementation of substantial infrastructure projects, the development and improvement of existing infrastructures.

It should be noted that the construction of modern, high-quality and large-capacity infrastructure projects is carried out primarily by the state in economically developed countries. In the course of implementation of infrastructure projects, first of all, work is being done to reduce the demand for investment, and after these costs are identified, these costs are paid by the state (Armenia et al., 2017).

Infrastructures are field of science, capital and labor. Infrastructure does not produce a product, but actively participates in the economic process, reduces the cost of the product, improves its quality, and affects the payment of the consumer demand as soon as possible. Although infrastructures fulfill important functions in economic activity, they do not have the 
ability to directly repay funds for their creation and development. However, the government, knowing the nature of the infrastructure, uses funds from the budget, and allocates funds for the creation and development of infrastructure that is in urgent need. If this work is carried out continuously, it will affect the macroeconomic balance policy in the country and may result in the deficits of funds allocated to the development of other sectors. Therefore, in order to ensure the elimination of such cases using the best practices in infrastructure development and improvement can be made. The most important of these is the use of public-private partnerships in the creation and management of infrastructure, as well as the best practice in their improvement.

Researching show that cooperation between state-private enterprises has been widespread in the practice of leading world countries in recent years in the creation, development and improvement of infrastructure, which is a region of labor and capital. Depending on ownership, property responsibility, who is in charge of management, the level of local authorities and private ownership, they act differently. However, despite what form they perform, the state authorities always keep their control function in their hands.

In some cases, the operation of the infrastructure division of labor in the state administration features in their design, construction and other works are entrusted to the private sector. In the other case, private partners undertake the financing, utilization and management of fixed assets. While investigating the experiences of advanced countries of the world to improve the infrastructure, it became clear that the representatives of public and private sector infrastructure services do not bear the same responsibility.

In many developed countries, the funds allocated by public-private partnerships are collected in a single central unit. Each manata used is strictly and bi-laterally controlled ( Bazhenov, 2012 ). As a result, infrastructure projects completed at the end of financial costs and loss or with minimal losses. The majority of such projects the infrastructure service costs maximum approximation to the real costs. The cost of the project is paid for by the user with the help of this project, which protects the companies.

Features of infrastructure development in developed countries

Funds allocated to infrastructure, including community-service infrastructures, roads, links and parks in many major US cities, are funded by new users. For this purpose, the Development System (System Devolopment Charge, SDC) operates in the administrative-territorial area of each settlement. Through this Development System, cash collected from residents is spent on improving people's social welfare, including creating, developing and improving infrastructure that serves people.

During the study of France, it became clear that, while implementing a financially viable infrastructure project in France, revenues were identified by allocating funds between authorities and operators to identify new funding sources and use them in the creation, development and improvement of infrastructure. This reduces the state budget from the heavy budget during the creation of infrastructure, or reduces budgetary costs in that direction.

In France, a fund of fundraising for the development of the system is being created and utilizing it to develop and improve the utility services and other infrastructure services.

In France, the use of the service infrastructure, improvement and increase of efficiency are important issues. For example, the use of the water supply infrastructure, and timely payment of funds, abuse of the rules and so on written contracts, as well as items. According to these substances: - "... the connection of all objects to the main line during water supply must be combined with the meter;" "Costs of the first connection are paid by the subscriber;" or "If there is a distance between the object and the main water line (n), the connection to the main line is combined with payment by the subscriber in any way".

There are serious concerns in the England when privatizing state-owned enterprises, including stateowned infrastructure (Verreault-Julien, 2017). Thus, when privatization of water supply infrastructure, one of the largest infrastructure facilities in the country, serious difficulties have arisen because of the fact that revenue from water supply has not yet been established and the precise mechanism for calculating ownership between owners and consumers. It required a strong, independent and decentralized organization to resolve the issue. Financial sources of such an organization should be based on revenue from water supply. Even though the water supply enterprise was ineffective, it had to operate. There are many losses because of investments in this sector is considered to be unsatisfactory.

Britain's experience gives reason to say that privatization of infrastructure facilities, even sophisticated, well-developed institutional areas of the state, though, so you have to be careful and cautious. Making a hasty decision in this area can lead to suffering.

Reforms in water supply, construction, transport, sewerage, utilities and other infrastructure areas and improving these areas require significant responsibility and longer time (Gokzhayeva and Ponomareva, 2014).

Based on advanced international experience, other aspects of the state-private infrastructure 


\begin{tabular}{|c|c|c|c|c|c|c|}
\hline Impact Factor: & $\begin{array}{l}\text { ISRA (India) } \\
\text { ISI (Dubai, UAE } \\
\text { GIF (Australia) } \\
\text { JIF }\end{array}$ & $\begin{array}{r}=1.344 \\
=0.829 \\
=0.564 \\
=1.500\end{array}$ & $\begin{array}{l}\text { SIS (USA) } \\
\text { PИНЦ (Russia) } \\
\text { ESJI (KZ) } \\
\text { SJIF (Morocco }\end{array}$ & $\begin{array}{l}=0.912 \\
=0.207 \\
=4.102 \\
=\mathbf{2 . 0 3 1}\end{array}$ & $\begin{array}{l}\text { ICV (Poland) } \\
\text { PIF (India) } \\
\text { IBI (India) }\end{array}$ & $\begin{array}{l}=6.630 \\
=1.940 \\
=4.260\end{array}$ \\
\hline
\end{tabular}

management, development and improvement of infrastructure are as follows:

1. Rent;

2. Joint venture;

3. Industrial areas (neighborhoods).

Lease is property, land and other natural resources that are contractually contractually payable and have the right to use them. It is allowed in all areas of the lease and can be applied to the property of all forms and types of property.

The right to lease the property belongs to the proprietor, his / her authorized agents, organizations and individuals, as ell as to other property rights to lease the property.

State and municipal property objects for the lease of legal entities and physical persons of foreign states shall be granted only with the consent of the proprietor.

\section{Features of lease agreements}

Any legal or natural person may be a lessee. The lessees have the right to create associations, unions, other associations based on their voluntary contributions, fund their activities and, in accordance with statutes, freely leave them.

The main document regulating the relations of the tenant with the tenant is a lease agreement. The leasing agreement includesthe following: the composition and value of the leased property, the amount of the leasing fee, the terms of leasing, attitude to the possibility of second-hand leasing of property (re-leasing the leased property),the duty division of parties in the field of full reconstruction and repairing the leased property, the duty of leaser to give the property to the leaseholder in terms of the agreement, the duty of leaseholder to use the property in terms of the agreement, the duty of leaseholder to pay the rent and to return the property to the leaser in a way as conditioned in agreement after the termination of it.

When state-owned property is owned by enterprises and organizations funded by the state budget, except for the cases specified by law, rental fees are transferred to the state budget at 100 per cent and 50 per cent of commercial enterprises and organizations remain at the disposal of those enterprises (Katina and Keating, 2015).

The control to the receipts of lease of stateproperty is carried out by relevant executive authority. When dealing with leasing and leasing businesses, the contract may include a progressive reduction of the amount of dotation, loss-recovery, profitability commitments, and lease payments. The lessee may give concessions on the amount of lease payments to lessee-owned and lessor-owned stateowned enterprises.

Lease of property does not result in the transfer of ownership of the property. Property and income received by the lessor as a result of use of the leased property, as well as the property acquired by the leased property, are his property. Unless otherwise provided for in the lease agreement, the lessor may, in the leased premises, be constructed at the expense of the lessor, with the consent of the lessor. When the contract expires or the contract is terminated, the lessor shall pay the lessee the market value of those premises and facilities.

\section{"Joint venture" analysis}

The term "Joint venture" was first used in the West in the nineteenth century and was widely spread in the twentieth century. Initially, enterprises were forced to carry out large-scale projects in extractive industries and in construction, and then the process of intensive production of such enterprises took place in the manufacturing industries.

In the Western economic literature, the enterprise is characterized as a form of the right of the organization of international business and its following signs:

- The joint venture is created partly by the assets of two or more parties, or capitalization of each partner;

- The enterprise may engage in production, trade, finance, research and development;

- Responsibility for governance among the parties;

- capital investment is long-term;

- entrepreneurship covers only a portion of the participants' activities;

- The risk of profitability and entrepreneurship is raised in proportion to the share of each of them in the capital investment.

The Joint venture deals with the planned, created, controlled and managed rights of two or more country partners as an independent investor. Broadly speaking, the venture operates production and trading activities based on contractual and cooperative relationships in the production and transmission spheres of the two or more partners in the scientific, technical, investment, service and other fields. More precisely, it can be achieved by minimizing production costs, minimizing costs, facilitating access to new markets and facilitating access to cheap resources, minimizing vulnerabilities (resource and technology failure, lower management knowledge), and ultimately higher earnings is the most promising form of co-operation agreements between two or more Partner countries in order to achieve this goal.

The basic principles of the formation and development of entrepreneurship can be achieved through the cooperation of some partners.

The common purpose of joint venture is to ensure long-term earnings by a partner enterprise. This functional purpose can be achieved by different methods. For example, providing access to new markets, reducing production costs, raising 
competitiveness in the marketplace, reducing the impact of risk on their business activities through cooperation among partners, and so on. Motivation to create entrepreneurship is diverse and covers all aspects of the company's business strategy (Kasymli, 2014). The company's strategy dominancy of any motive can rarely, usually gets a lot of reasons.

Thus, at certain stages of economic development, certain contradictions are in the interests of partners. Joint selection of business partners is very important. Success or failure in business activities largely depends on the solution of the issue of selecting partners. The exsperiment of businessmen proves that it is not right to connect with people you have not met and become a partner with people you do not know well. Partner: if supplier, customer and buyer are not friend, you should be familiar with him at least. Collection, systematization and in-depth analysis of information about a potential foreign partner is the most responsible stage of entrepreneurship.

At the moment there are many sources of economic information collection and acquisition. There is a widespread network of information, marketing and consulting firms involved in collecting and studying information in the Western states. The best sources of information access are the official publication of statistical information, celebrated media, the Internet.

\section{Comparative analysis of industrial regions of different countries}

It is built on the territory specially allocated for industrial development. The first examples began in 1960 as the establishment of Free Economic Zones in production (industry) in various forms. These zones were built around maritime ports mainly in countries with very cheap labor force. At the same time, industrial (industrial) oriented regions were established in developed countries and even in socialist countries (in 1967, in Belgrade, Yugoslavia). The creation of production-oriented Free Economic Zones has contributed to the development of large-scale production and, thus, the transfer of relevant technology and knowledge. Along with such industrial areas, industrial zones ("industrial neighborhoods"), which, as a rule, have no special economic privileges (tax and customs privileges) have begun to form (Ministry of Economy...).

In industrial neighborhoods, several other incentive advantages are provided, in addition to infrastructure (electricity, gas, sewerage, buildings and structures) and management services. The number of these advantages and the duration of implementation depend on the general economic and industrial policy carried out in the country and vary from country to country. The stimulating benefits offered in some countries are as follows:
- long and short-term loans with low interest;

- The subsidy of rentals of ready and modern buildings (hangars) and devices;

- Water and electricity subsidies;

- Subsidies for communication services;

- Tax incentives;

- A window system for entry to the neighborhood;

- Joint use of production areas, equipment and services;

- Residential buildings for workers.

International experience in emerging and recently-developed industrial neighborhoods is given in the example of the following countries.

In the Republic of Turkey, there are 456 industrial neighborhoods where about 500,000 people are employed. They have been established by industry co-operatives since 1965 with the support of the Ministry of Science, Industry and Technology. The main objectives of building industry neighborhoods are as follows:

- provision of jobs in accordance with sanitary regulations and increasing labor productivity;

- transformation the small businesses into medium enterprises and achieve of technological development;

organization of planned urbanization and thus prevention of environmental pollution;

- Extension of Vocational Education through the joint initiative of the Ministry of Education and the Ministry of Science, Industry and Technology (there are private vocational schools in about 100 industrial neighborhoods and educational centers in 140 industrial neighborhoods).

The largest of Industrial Estate is "Aykosan" Industrial Estate ("Aykosan Sanaye Sitesi") with 86 hectares of areas (64 hectares of buildings) and the smallest of Industrial Estate is "Bıksan" (Bakırköy ) with 4.700 hectares (5.8 hectares of buildings). Anchorage area for rent in industrial neighborhoods starts at $60 \mathrm{~m} 2$. During the construction of the industrial block, $\$ 280$ will be allocated for the construction of a building (anarchy) with the norms of 2013.

$50 \%$ to $70 \%$ of the cost of setting up an industrial block by the Ministry of Science, Industry and Technology is provided at least for a period of 11 years. In the first year after the submission of the loan to repay the loan, no payments shall be made.

Industrial neighborhoods in the Great Britain are a highly developed mechanism. Thus, the Trafford Park, industrial park in Manchester, England, is considered to be the world's first planned industrial zone. Trafford Park, the largest industrial district in Europe, has 10 industrial neighborhoods and warehouses, geographically separate from each other (Albrecht, 2017). Generally, in many parts of the Great Britain, especially in smaller towns, there 
are a large number of private industrial neighborhoods. These neighborhoods include about 10-50 hectares of land and 50-100 m2 of rental areas (Piyatrapoomi et al., 2004).

In the Republic of Kazakhstan, a number of documents were adopted in 2006-2010, which enabled the development of industrial zones (neighborhoods) in the country. At present Kazakhstan is working on creation of 15 industrial subdivisions. The Ministry of Economic Development of the Russian Federation has developed a project of methodological recommendations on creating industrial neighborhoods. According to the draft document, the industrial block is created on the initiative of the local executive power, municipality or the private sector in the subjects of the Russian Federation for the purpose of development of small and medium enterprises.

At present, the work on preparation and coordination of a single draft document on industrial block in the Republic of Belarus is underway. Industrial neighborhood is designed to support production or scientific research activities of small and medium-sized enterprises. The leading activity in the establishment of the neighborhood is divided into local executive bodies and local executive authorities must employ local associations and unions to work closely in the establishment of the neighborhood. The selected land is leased to the organization, its area must be at least 10 hectares, the distance from the main communications should be at least $20 \mathrm{~km}$. The area should be provided with adequate infrastructure (heat and electricity, water supply, domestic and industrial wastes utilization, firefighting service, transport communications, communication services, etc.). Funding for the creation of an industrial block can be made at the expense of central executive power, local executive power and management company. Also, the private sector can be attracted to the private sector scheme. Malaysia has about 600 industrial zones (free zones, technoparks, science parks, industrial neighborhoods, etc.) and nearly 200 industrial neighborhoods. Most industrial zones have been established by the State Economic Development Corporation, Regional Development Agencies, seaports and local executive authorities. Additionally, in some provinces, industrial neighborhoods are built by private companies.

There are 18 small and medium-sized industrial sites in Sri Lanka and all of them are managed by the Industrial Development Council. The concept of "The Mahinda Chinatana" is aimed at improving the geographical structure of industry through the establishment of industrial neighborhoods, thereby addressing the inequality in the development of industry between the city and the region. It is planned to build 5 new industrial neighborhoods in
Sri Lanka in the following years. Some industrial sites are planned to be built with the financial support of foreign countries. For example, construction of Atchchuveli industrial zone in Jaffna province is carried out with the support of the Indian Government. (http://senaye.gov.az).

In the Republic of Azerbaijan, the construction of large infrastructure projects in the regions has been carried out by the state since 2004. However, the decline in oil revenues compared with previous years and the relative decline in state budget revenues have created serious difficulties in the implementation of infrastructure projects in recent years. In order to achieve strategic goals, the creation of private sector interests in the implementation of infrastructure projects and, in this case, involving public funds can also be economically beneficial. Because of the state support in Azerbaijan, entrepreneurial class, which has considerable financial potential, has been formed.

During the construction of large infrastructure facilities, the economic mechanism of public-private partnership projects should be developed, reconstruction and development of international and development banks should be ensured.

The involvement of private equity in infrastructure projects is a serious responsibility for the government and its institutions, as well as developed banks. Their main task in this direction is to prepare and implement this mechanism for managing the infrastructure design risk and spending of funds to be invested.

Given the decline in aggregate demand and shortage of financial resources in the context of the global economic downturn, it is expedient to issue bonds to circulation at the expense of the active funds of certain development banks in order to accelerate the implementation of large-scale infrastructure projects and ensure the completion of projects financially.

\section{Implementation of infrastructure projects}

At the same time, it should be noted that during the implementation of infrastructure projects that ensure the sustainable development of the economy of the Republic of Azerbaijan in the modern times, some problems may arise depending on the current situation (Mir-Babayev et al., 2017). Based on the research, the problems that may arise during the implementation of infrastructure projects can be summarized as follows:

- Any deficiencies and deficiencies can be avoided due to improper maintenance during planning and optimization of existing infrastructure projects;

- To improve the effectiveness of infrastructure projects, we must strive to successfully fulfill contractual commitments on resource provision, 
otherwise, the integrity of the infrastructure can be violated due to the lack of raw material and material;

- The human resources needed to manage hightech infrastructure projects can not cope;

- The high level of administrative barriers that may exist in the management of infrastructure projects, the likelihood of corruption and bribery, and other problems that may delay the development of infrastructures in Azerbaijan.

Looking back over the past, we see that one of the most important problems that arose during the construction of infrastructure projects was the failure to carry out serious, effective control over project finance and implementation of costs. When the control mechanism is weak, sometimes cost can be artificially increased, the projects can not be implemented at the required level and during the required period, resulting in lower quality of service, with the cost of the facility being reduced.

The modern economic development of the Republic of Azerbaijan allows the implementation of large-scale infrastructure projects that provide sustainable economic development through the state's financial costs. However, the study of advanced international experience, governmentdriven policy, the development of the private sector and the allocation of funds in this direction, suggests that in the future private sector can be involved in the construction of infrastructure projects. For this reason, the financial system needs to be reestablished through efficient management of infrastructure projects, strengthening market mechanisms and expanding the fair competition market.
This approach can also improve the physical and cultural well-being of the population by influencing the creation and development of infrastructure.

\section{Conclusion}

By summarizing the carried out studies, it can be concluded that it is important and important for the elimination of existing problems and improving the development of infrastructures affecting the sustainable economic development of the Republic of Azerbaijan:

1. Using public-private partnerships in the implementation of large-scale infrastructure projects in Azerbaijan, taking advantage of the advanced experience of the global economy;

2. Implementation of innovative infrastructure projects on the basis of public-private partnerships, in order to increase the effectiveness of the work, to implement a management system in the form of regulatory and control;

3. It may be expedient to use the financial policy attributes of the financial market of Azerbaijan when building large infrastructure projects at the expense of private companies.

In our view, the application of the proposed recommendations to the economy can ensure sustainable economic development in our country, influencing the economical costs of our country living in a war-time, as well as influencing the creation and development of socio-economic infrastructures.

\section{References:}

1. Albrecht B.C. (2017) Positive public economics: reinterpreting 'optimal' policies. Journal of Economic Methodology. 2017. 24(1), p. 90-103.

2. Armenia S., Tsaples G., Carlini C., Volpetti C., Onori R., Biondi G. (2017) A system dynamics simulation tool for the management of extreme events in urban transportation systems. International Journal of Critical Infrastructures. 2017. 13(4), p. 329-353.

3. Bazhenov A. (2012) Public-private partnership is the only mechanism for the development of the Far East. Industrialist of Russia. 2012, No. 7-8, p. $35-40$

4. Gokzhayeva E.B, Ponomareva M.A (2014) Regional economy: infrastructure problems.
Rostov on Don: Publishing house "AssistanceXXI century", 2014, 160 p.

5. Kasymli V. (2014) Economic modernization. Baku: Center for Strategic Studies under the President of the Republic of Azerbaijan., 2014, $311 \mathrm{p}$.

6. Katina P.F., Keating C.B. (2015) Critical infrastructures: a perspective from systems of systems. International Journal of Critical Infrastructures. 2015. 11(4), p. 316-344.

7. (2017) Ministry of Economy of the Republic of Azerbaijan. Available at: http://senaye.gov.az (Accessed 12.12.2017)

8. Mir-Babayev R., Gulaliyev M., Shikhaliyeva S., Azizova R., Ok N. (2017) The Impact of Cultural Diversity on Innovation Performance: 
\begin{tabular}{l|lr|ll|ll} 
& ISRA (India) & $=\mathbf{1 . 3 4 4}$ & SIS (USA) & $=\mathbf{0 . 9 1 2}$ & ICV (Poland) & $=\mathbf{6 . 6 3 0}$ \\
Impact Factor: & ISI (Dubai, UAE) $=\mathbf{0 . 8 2 9}$ & PUHЦ (Russia) $=\mathbf{0 . 2 0 7}$ & PIF (India) & $=\mathbf{1 . 9 4 0}$ \\
& GIF (Australia) & $\mathbf{0 . 5 6 4}$ & ESJI (KZ) & $=4.102$ & IBI (India) & $=\mathbf{4 . 2 6 0}$ \\
& JIF & $=\mathbf{1 . 5 0 0}$ & SJIF (Morocco) & $=\mathbf{2 . 0 3 1}$ & & \\
\hline
\end{tabular}

Evidence From Construction Industry of Azerbaijan. Economics and Sociology. 2017. 10(1), p. 78-93.

9. Perry M. (2010) Controversies in Local Economic Development. Local Economy. 2010. 25(7), p. 527-534.

10. Piyatrapoomi, N., Kumar, A., Setunge, S. (2004) Framework for investment decisionmaking under risk and uncertainty for infrastructure asset management. Res. Transp. Econ. 8 (4), 199-214.

11. Verreault-Julien P. (2017) Non-causal understanding with economic models: the case of general equilibrium. Journal of Economic Methodology. 2017. 24(3), p. 297-317. 